\title{
Nataša Lah \\ Hidden Ekphrasis in the Works of Miroslav Krleža
}

\begin{abstract}
"I am contemplating the term Ars scribendi. This skill, both dangerous and descriptive, what is it comprised of? Of writing or of observing? ... What is the core, and what is the shell of this labour? What does it mean to peel while writing and can we, truly, peel anything with writing"?

M. Krleža, diary entry, ${ }^{\text {rd }}$ August 1920
\end{abstract}

Keywords: Miroslav Krleža, belletristic cryptogram, hidden ekphrasis, fictional content of ekphrasis, ekphrasis and reality

DOI: 10.4312/ars.11.1.118-133

The starting point for researching hidden ekphrasis in the extensive works of the writer Miroslav Krleža (Zagreb, 1893 - Zagreb, 1981) was the unpublished doctoral thesis of this paper's author, defended under the title: Likovne koordinate $u$ djelu Miroslava Krleže (Visual Art Coordinates in the Work of Miroslav Krleža, Lah, 2009). Among other topics, the thesis researched, analysed and simultaneously systemised the author's wide use of "belletristic cryptograms", whether used in essays, plays, novels, novellas or diary entries. ${ }^{2}$ The term cryptogram is a type of riddle that can be solved only after one finds the key to its solution. In every text written by Krleža, there is literally a "key work" that is included, demanding to be noticed. Krleža has woven many descriptions of artworks from the rich resources of European art history into his own texts. The inclusion of such prototypes is usually defragmented, using methods that apply unexpected, fictional or real moments of the plot into descriptions of paintings and sculptures. This process cleaves the image, making its description more or less faithful to the original. The "key work" then casts aside all doubts that the literary depiction of the real world was indeed plausibly pointing towards its own source of fascinated observation. Thus, for example, in describing the closing scene of the novel The Banquet in Blitvia, the author uses the visual template of Géricault's The Raft of the Medusa. Since the fragments of the description are familiar to all who are acquainted with this painting, an additional connection to this piece of art is made by naming the hotel in the plot "Medusa". Furthermore, the same happens in the play Messrs. Glembay, in describing the character of Sister Angelika, where Krleža uses

1 Krleža (1977a, 336); this quotation, as well as all quotes used in his text, were freely translated from Croatian by the author of this paper.

2 The dissertation was based solely on researching the literary prose produced by Miroslav Krleža. 
Holbein's painting of Lais of Corinth but never mentions it directly; yet Leone, at one point, utters: “... your face reminds me of and old Holbein head: I believe I saw it in Basel."3

We can find many similar examples in Krleža's work, from the early plays such as Michelangelo Buonarroti (first published in the magazine Plamen in 1919), to texts written and/or revised in the 1970s. This paper will discern but a few "belletristic cryptograms" related to descriptions of visual artwork in order to utilise the term "hidden ekphrasis" when talking about the phrases in question. The cryptogram style of introducing ekphrasis into the text determines its concealment. A visual template of the described artwork, according to the type of cryptogram discerned, is defined as ekphrasis. As Tamar Yacobi suggests: "This goes to show that ekphrasis, the literary evocation of spatial art, is an umbrella term that subsumes various forms of rendering the visual object into words - so various, indeed, that both the reference and the sense of the term in critical discourse leave a good deal to be desired" (Yacobi, 1995, 600).

Additionally, this paper introduces a method of grouping the ekphrasis on the basis of the role it plays in the text in order to note differences between descriptions of paintings that were "borrowed" from the real history of European art and used to corroborate the re-contextualisation of Krleža’s life and work. The matrix Krleža uses to mirror historic art on the fictional canvas of his day and age is the matrix of "ethical intelligence", which presumes the artist to be present in the world he witnesses or, to use contemporary vocabulary, it demands an artist's engagement and his artistic activism. Krleža does not advocate ideologically utilitarian art, but rather an artistic responsibility in interacting with the world. In the spirit of the accepted social role of artworks, he cynically applies phrases such as "aesthetic conscience". A prerequisite for the authenticity of an artwork is its faithful testimony of reality. In this sense, reality is faithfully expressed in descriptions of villages by Brueghel the Younger or Krsto Hegedušić; in descriptions of cities, where Georg Grosz had the leading role; in descriptions of human suffering and passionate rebellion by Géricault or Goya; in descriptions of philistines by Daumier; in descriptions of battles by Piero della Francesca or in the "portrayal" of contemporary war by Otto Dix; while the clergy and the aristocracy are most realistically depicted by Holbein and Velasquez ... and so on.

To Krleža, it is very important that one does not cross the line of reality when evaluating art. Within the forbidden zone of nonreality there lies the art of mimetic illusion, art in the service of political manipulation, decorative historicism, academism, Biedermeier or art nouveau, while on the other side there is the l'art pour l'art attitude, standing eye-to-eye with abstract painting, for such artistic forms are a declaration of 
social escapism, worthy of intellectual scorn. Of course, style without attitude could not witness reality, but it certainly could mimic the truth in reality, and thus Krleža's ekphrasis is used to describe many works of art that he in fact held in very low regard. This was all done in his fictions, memoirs and essays, with the intention of stigmatizing the petty bourgeoisie who promoted such artworks. This is especially evident in his creation of mise-en-scène, laden with detailed art descriptions or dialogues that upstart characters have about celebrated artists.

There are also many instances in the literary works of Miroslav Krleža where fictional characters happen to be painters. These include Michelangelo Buonarroti from the titular play, Leon Glembay from the play Gospoda Glembajevi (Messrs. Glembay), Aurel in the play Leda, Filip Latinovicz in the novel Povratak Filipa Latinovicza (The Return of Filip Latinovicz) and both Rajevski and Larsen in the novel Banket $u$ Blitvi (The Banquet in Blitvia), to name but a few.

Within the distinctive existential framework of fixed social, ancestral, historic, cultural and political circumstances, the aforementioned protagonists create a tense rapport between their artistic views of reality and the actual reality in which the artists are immersed, but never truly reconciled with. In verbal disputes, such as the one between Filip and Kyriales in the novel The Return of Filip Latinovicz, or between Michelangelo and the Unknown One in the play Michelangelo Buonarroti, or between Aurel and Oliver in the play Leda ..., the artists' visions clash with opposing arguments of reality, personified so as to support the fictional dialogue form. Such dialogues, in their tense opposition of arguments, result in the transgression of a debate on the aesthetic dimensions of a work of art. Not only is art firmly blended with reality, it is also a seemingly corrective measure for the artist's credibility as an author. This is the level at which Krleža sets two equivalent methods, albeit overall different, of interpreting paintings. On one level, there is a clash of reality and art manifested through the "transfiguration" of artistic realities into fiction, ${ }^{4}$ where actual and real artists or actual and real works of art "epitomise" historic reality; while, on the other the sustainability of artistic fiction in reality itself is questioned by actual and real artists, and actual and real works of art, "intervening" in reality in the guise of a remedial measure and/ or as a form of collective conscience. In both instances, Krleža requires and utilizes, in the form of concealed ekphrasis, real works of art from the rich repertoire of art history, highlighting works that had paradigmatic and rhetorical effects on the history of great European cultures, as well as less-influential works of art from the political constituencies of ex-Yugoslavia.

4 The term "The Transfiguration of the Commonplace" in this text is used in accordance with Arthur Danto's interpretation, as proposed in his book The Transfiguration of the Commonplace: A Philosophy of Art, 1981. 


\section{Real within the fictional}

"Each and every thing that can trigger associations, that carries within itself the magnetic power of inspiration, can never be a direct copy or a replica of the form itself."

M. Krleža $(1952,7)$

Michelangelo's real fresco depicting scenes from the Old Testament Book of Genesis ${ }^{5}$ is set in the fictional realm of the drama Michelangelo Buonarroti, which contemplates the social role of a creative act in the High Renaissance, when the idea of a creative genius was first voiced and brought forward. Krleža builds his play by propping up the impression that this path to gaining independence is bloody and difficult, in addition to being inherently uncertain in some measures. In a different context, Krleža brings forth the Sistine Chapel $^{6}$ and Michelangelo's work yet again. This time, the protagonist is brought before The Last Judgement. ${ }^{7}$ This work of art is described in the novel $\mathrm{Na}$ rubu pameti (On the Edge of Reason), in the chapter "Intermezzo at the Sistine", and is depicted in a scene where the nameless hero (the first person singular narrator) clashes with "human stupidity" as a metaphor for a world with which the narrator has no common grounds. Within the narrative of the "Intermezzo", while describing Michelangelo's fresco of The Last Judgement, the narrator compares the artist's vision of "a cursed cataract" ${ }^{8}$ with contemporary European civilization as represented by a swarm of tourists - “... even-toed ungulates bleating and staring into the dark abyss of human desires and human reason..." (Flaker, 1999, 76).

The nameless narrator describes Michelangelo's Last Judgment with the following words:

At the foot of the very scene, above the sacrificial altar, a great flood, cerulean blue, dark-dim-maroon in colour, cascading against a cliff, like a dark waterfall, bringing down in its path a swarm of agitated castaways into the bottomless abyss, into the chasm that gapes behind the altar, into hell itself. In the demonic spell, cast upon this cursed cataract, there are suspended in midair, floating, forms of the distraught drowned, fleshy clusters of the entire

5 Michelangelo Buonarroti is a fresco composition on the ceiling of the Sistine Chapel, comprised of nine rectangular panels depicting the Book of Genesis. It was created between 1508 and 1512 during the pontificate of Pope Julius II.

6 Cappella Sistina - originally, "the papal private chapel" was built within the complex of the Vatican Palace in Rome, as designed by Baccio Pontelli, in 1481 during the pontificate of Sixtus IV.

7 Michelangelo Buonarroti, The Last Judgement, an altar fresco of the Sistine Chapel; it is painted on the west wall of the chapel, behind the altar. It was created between 1535 and 1541 during the pontificate of Paul III.

8 Latin cataracta waterfall, portcullis, from Greek kataraktēs, from katarassein to dash down, from kata- + arassein to strike, dash. 
stark-naked humanity falling through this very orifice into nothingness; it props itself in a curvet, it jostles away, prays, begs, hollers and screams like a heathen; it is all just a surge of the waving crimson red banner, which the deceased has presented to us as a mysterious sign before his own final departure: flaunting once more its dark-dim-maroon banner, it disappeared into nothingness... (Krleža, 1960, 264).

In the play/novel Messrs. Glembay, the writer utilizes yet another real and significant work of art by the North European renaissance painter Hans Holbein the Younger, Lais of Corinth. ${ }^{9}$ The description of Holbein's painting has several functions. Primarily, it is an illustrative example of the entwined layers of the real and imaginary, all with the goal of accentuating the question of beauty, although not aesthetic beauty, but rather the type of beauty Krleža depicts as "the beauty of ethical intelligence".

Here is an example of Krleža's hidden and defragmented ekphrasis of Holbein's Lais:

She is lean, dignified and decorative, without a drop of blood in her cheeks, with translucent lily-white hands, which she flirtatiously hides in the rich folds of her sleeves. ${ }^{10}$

Oval face of a graceful geisha ${ }^{11}$, a child's face, laughing, creamy with a hue of underlying pastel tones. Her eyes are like that of a Holbein; intelligent, bright, and somewhere deep within a transcendent sheet with an almost imperceptible phosphorous light of eroticism. [...] I speak of Holbein, my dear Sister Angelica! Of an old Basel Holbein, I've been contemplating for seven years! That face was smiling, just enough for the apples of the cheeks to form two discreet dimples, like two symmetric shadows above perfect lips of a Diana figure, hands of lily-white, fragrant, English fingers, fine, elongated Holbein's fingers, a divine blueblood hand such as only Holbein himself could possibly have seen $!^{12}$

Beatrice's face is one from the Trecento, Quattrocento, her gaze, her Holbein's oval contour... ${ }^{13}$

9 Hans Holbein the Younger, Lais of Corinth, 1526., 34.6 x $26.8 \mathrm{~cm}$, oil on wood, Kunstmuseum Basel, Switzerland.

10 Krleža (1977, 223): Angelika’s description (Act I).

11 Lais was inspired by an actual person from Greek history; that of an educated mistress of the philosopher Aristippus. The connection with geisha is thus clear, as they were companions/mistresses in ancient Japanese aristocratic circles, whose function was to entertain men. To achieve this, they went through special training that started when they were still young girls, and each developed their own artistic skills (singing, dancing, playing an instrument, or rhetoric). Etymology of the word: Japanese, gei: art + sya: person.

12 Krleža (1977, 229); dialogue with Sister Angelica (Act I).

13 Krleža $(1977,236)$; excerpt from a conversation with Alojzije Silberbrandt, the baronesse's confessor 
Your hand is as cold as camphor! Your Holbein hand, Beatrice! ${ }^{14}$

In the play Leda, the appearance of "measly" decorum in the visual arts leads to parody. Krleža associates style with the current fashion and imagination with artists' attitudes. To illustrate the true nature of narrative kitsch, he describes the ceiling decoration painted by Hans Makart which was commissioned by Emperor Franz Joseph I in the $19^{\text {th }}$ century. The ceiling art depicts Shakespeare's A Midsummer Night's Dream, and was painted at the Hermesvilla. ${ }^{15}$ The description of the painting, as set within the cultural and political context of its creation, is revealed to be the same as the de rigueur Biedermeier tastes of the period, a period slyly mocked by the "sneering wraith" of the First and Second World Wars. Furthermore, it must be noted that the very title of the play is related to the production of erotic paintings aimed at the less educated and affluent $19^{\text {th }}$ century middle-class, among whom the mythological motif of Leda and the Swan was especially marketable and popular, a trend to which Makart greatly contributed.

The main protagonist of the novel The Return of Filip Latinovicz is the painter Filip Latinovicz, who distinguishes and identifies two different pursuits: that of his own self and that of his artistic identity. The nature of Filip's artistry in this novel has been the topic of numerous studies. This paper will, on the other hand, focus on a lesser aspect with the aim of bringing forth all the artistic approaches Krleža used to articulate Filip's art. This technique can, in principle, be called a collage ekphrasis. Using a wide range of known artworks, the author portrays three different levels of Filip's artistic creation: as paintings hanging in rooms Filip enters, as mental images Filip filters through using his "own sensitive affinity", and as imaginary scenes he wishes to depict on canvas. Wishes, but fails. By using imagery drawn from the rich pool of artistic heritage from the early avant-gardes of European modernism, Krleža draws both images and their fragments, disassembles them and patches them together in the form of a collage. Primarily, he is focused on a subdued, anxious symbolism like that of Edvard Munch, as well as on the excited, yet apprehensive fauvism we find in the works of André Derain. Krleža uses his collage ekphrasis to wrangle with Expressionism, which he

and her son's tutor; Beatrice is the widow of Leone's brother Ivan, who became a nun and took the name Angelica. She is the only member of the Glembay family Leone respects, and with whom he has a close personal relationship. (Act I).

14 Krleža (1977, 362); finale (Act III).

15 The palace called Hermesvilla is located in Lainzer Tiergarten near Vienna, and was built on the hunting grounds belonging to the Habsburg nobility between 1882 and 1886. It was commissioned by Emperor Franz Joseph I for his wife, Empress Elisabeth. It was designed by the architect Karl Freiherr von Hasenauer, while the murals in the interior were painted by Hans Makart, Gustav Klimt and Victor Tilgner. The name of the villa refers to a statue of Hermes located in the garden of the villa. Other names for the villa include: the Castle of Dreams and Villa Waldruh. Hans Makart decorated the bedroom belonging to the Emperor and his wife in 1882, with the images from Shakespeare's A Midsummer Night's Dream. The decor in the room has remained unchanged to this very day. 
deems an escape from the realities and disorientation of a world that seeks an artist's sentient presence, as it is on the brink of great danger in the form of the First World War (Filip was written bearing that event in mind, which only confirmed Krleža's earlier attitude on the matter). Induced by the narrative intensity of expression in his artistic role models, who were a part of the German Neue Sachlichkeit ${ }^{16}$ movement, Krleža "punishes” Filip's escapism by not allowing him to find what he seeks. Filip, as a painter, lacks what Otto Dix or Georg Grosz have; an artistic objectification of their critical realism. As such, Krleža’s ideal was not manifested in Filip's painting, but was expressed through his perpetual (and never realised) desire for objectification. This is why the portrait of Filip's mother, described as a version of the Lady with Mink and Veil by Otto Dix (1920), was left unfinished. Filip was unable to overcome the problem he had with intimacy in relation to his mother, so he ultimately fled from the paining itself by "...sorting his brushes, taking the half-finished canvas to his room, placing it behind the wardrobe facing the wall, and leaving it at that" (Krleža, 2003, 61).

The "heroic" monumentalism of the painter Roman Rajevski in the novel The Banquet in Blitvia epitomises the "Vidovdan" idea" of the sculptor Ivan Meštrović. The writer meticulously describes the equestrian sculpture of Prince Marko, ${ }^{18}$ which was created in the "spirit of verbal dominance of the 'Vidovdan' slogans" (Krleža, 1932, 303) in order to depict the equestrian sculpture - "Barutanski of Beauregard on his Atlas, in monumental, colossal size" (Krleža, 2000, I, 156). The Banquet of Blitvia is, as defined by Krleža, a mythological cultural frame: “a romantic 'historiographic' opera, active to this very day in the heroic protagonists of the greatest, most celebrated painter, sculptor and political ideologist Roman Rajevski, equally revered in Europe and in both Americas." (Krleža, 2000, I, 11-12). Roman Rajevski, like Ivan Meštrović, embodies "a synthesis of the Blitvian folk mythos," (Krleža, 2000, I, 149), while his true opponent, Sigismund Larsen, is a subtle artist who creates from the depths of the subjective shroud of modernism, and is just one of many Blitvian artists. Krleža's model for the life and work of Sigismund Larsen is that of the painter Josip Račić. Larsen's death in the novel is described as suicide, and an act "... with no real motive, by all accounts, the consequence of a moment of weakness in 'a temporarily deranged

16 Neue Sachlichkeit was an artistic movement in the Weimar Republic, active from 1922 until it was banned by the Nazi regime. The most notable representatives include Max Beckmann, Otto Dix and Georg Grosz.

17 This is a reference to the partially finished architectural, sculptural cycle called the Vidovdan Temple (1908-1912) by the sculptor Ivan Meštrović, which ultimately became the "most political work in the sculptor's opus, as stated in: Srhoj, V., Ivan Meštrović i politika kao prostor ahistorijskog idealizma (Ivan Meštrović and Politics as an Arena for Ahistorical Idealism) v: Ars Adriatica 4.204, 362-384.

18 Ivan Meštrović, Kraljević Marko na Šarcu (Prince Marko on his Horse Šarac), bronze, 1910, the National Museum in Belgrade (source: http://www.narodnimuzej.rs). The sculpture was exhibited at the group exhibition of the Croatian artistic society Medulić in 1910, at the Art Pavilion of the Kingdom of Serbia at the International Exhibition in Rome, 1911. 
mind”" (Krleža, 2000, I, 112); while Račić “...a twenty-year-old, with strong beliefs in his own talent, was one day found in his hotel room with a gunshot wound to the head" (Krleža, 1932, 296). Finally, the chain of associations in the multi-faceted, pictorial and cryptic structure of Larsen's Nocturne ends with a description of the last self-portrait of Josip Račić, as if it were Larsen's “...a quiet man with strangely intense blue eyes” (Krleža, 2000, I, 118). “This is, in fact, Larsen's self-portrayed confession about his own life, his own tragedy, about himself, about his most intimate secret self, about the intellectual and moral scalp of the one Sigismund Larsen" (Krleža, 2000, III, 120) "...And the visage on that black velvet is the visage of a man who, for the love of one ludicrous idea, haemorrhaged profusely before all of Blitvia” (Krleža, 2000, III, 121).

But, true ekphrasis hides in the romantic image at the end of Nielsen's "adventure", which is also the conclusion of the novel itself. Niels Nielsen is an outlawed intellectual and a dissident the author identifies with on a scenic and picturesque "stage" of a foreseeable geographical space and a historically foreseeable time. ${ }^{19}$ The third book in The Banquet ends with the description of Géricault's Le radeau de la Méduse (The Raft of the Medusa). ${ }^{20}$ In a different context, Krleža writes: "with Géricault's death, French paining was dealt a heavy blow: in this shallow grave, many romantic ideas were laid to rest. ... Convinced that the greatest goal of painting is to be deeply moving and dramatic at all costs ... he is the source of one of the most prodigious developments in European painting of that age" (Krleža, 1959, 169). The obvious similarity of Géricault's painting with the image of Larsen's departure in a "barcas ${ }^{21} \ldots$ to an unreachable shore on which he will surely never disembark" (Krleža, 2000, III, 363) is not the only associative tool. By naming the hotel in the concluding scene "Medusa", the chain of pictorial associations is sealed.

\section{Fictional within the real}

"These memories serve only one purpose, and that is to abridge an entire system of thought, built upon optical illusions, into elements of reality." M. Krleža (1977a, 446)

19 As defined in: Flaker $(1993,47)$ referring to “...the Danube-Balkans region with Croatian, Slovenian, Hungarian and Serbian realities [...] mostly in the $19^{\text {th }}$ and $20^{\text {th }}$ centuries".

20 The painting was exhibited at the Paris Salon in 1819, marking a turning point in painting and the birth of high romanticism. Géricault's masterpiece caused controversy on both sides - on the one hand, it was a critique of the current government, on the other, it was a complete rejection of the established imperatives of neoclassicism. The content of the painting is based on a real event, when the French frigate Medusa ran ashore on the Banc d'Arguin in 1816. The captain, appointed by the king, abandoned ship along with his officers. The remaining passengers, 149 of them, floated on an improvised wooden raft for thirteen days. After surviving famine, cannibalism, mutiny and death, there were only fifteen people left alive when saved.

21 Norwegian: bàrkas; French: barcasse - a type of a medieval sailing ship. 
Another way of implementing ekphrasis in Krleža's writing is by questioning artistic fiction through the prism of reality. This is more about artworks and artists' attitudes focused on reality, rather than the illusion of represented reality. In what way have such works highlighted reality, i.e. how did they make it so transparent? Here, we are faced with the writer's critical activism, about which many theoretical texts have been written; including those that in engage in sharp debates over Krleža's relevance when it comes to judging art (especially with his criticism of modernism). However, Krleža never aspired to be a critic, and his works about art were written in the form of memoirs, essays or belletristic writing, while all the debates and political content within his works only confirm his interest in the intellectual exchanges of the aesthetic and communicative aspects of art within society. Krleža's so-called contraries have thus been scrutinised, but it is important to state that these do not stem from representing different views on life, but from different perspectives from which he described the world. On the one hand, he viewed it while idealising utopian delusions about its betterment; on the other, he viewed it with while cynically unmasking his own hopes. Looking at reality or the real world, such as looking out of a window, was very often looking into an image. Krleža's hidden ekphrasis is precisely that, a look from the inner world of intellectual subjectivism towards the public world of the street (urban or "agramske" and rural or "podravske", it's all the same). In this street, as Krleža, himself, wrote: “...the gargantuan maw of stupidity yawned before all ... This maw devours daily throes of corpses ... Let's be real! What is real? The only true reality is the Grim Reaper" (Krleža, 1977, 282). One question remains, how do we describe such a scene? According to Krleža, the closest image that comes to describing this viewpoint is Goya's Saturn Devouring His Sons. ${ }^{22}$ He does so "without the aesthetic remorse so important for our contemporary, modern-day art" ${ }^{23}$

Goya's painting of a "demonic temperament" is an expression of history. This expression is not historically neutral, but "an organic part of the social fabric it once belonged to" (Moxey, 2005, 151). For Krleža, Goya's thought is like that of Hobbs, Voltaire or Tolstoy, linked to "crystal clear, aesthetic and social objectifications".

In the proper tradition that developed since early romanticism towards high modernism, Krleža acts as an engaged critic of the contemporary art scene within a historic and political situation where, according to him, an artist needs to steer clear of primitivism, snobbism, idolatry, and mere "creation for creation itself". For Krleža, true imagery is, as is all great art, similar to a well of impressions which glimmer and echo through the experiential development of life, literally “... the glimmer of transparent images in a corporeal looking glass" (Krleža, 1952, 7). The transparency of the image

22 Francisco Goya, Saturn Devouring His Son, c. 1819-23., oil on canvas, Museo del Prado, Madrid.

Paraphrased using Krleža’s preface in the monograph of Augustinčić A. from 1968. 
does not signify that the depicted scene is lacking, but instead that this transparency is provident, activating our innate ingenious ability to observe. Through a translucent image, as Susanne Langer would say, "we use our mind's eye to see" (Langer, 1967, 221). On the other hand, "the political aspect of art," if we are to consider the notes from A Childhood in Agram, deal with our need to synthesize art and reality in order to finally break free of baroque hallucinations and head towards "a verified experience of the experienced." ${ }^{24}$

There is a vast source of ekphrasis in Krleža's notes from Days Long Past. ${ }^{25}$ They are all links to reality, and the examples range from the very broad towards subtly levelled nuances. The descriptions can be categorised into those which have a primarily aesthetic, critical, or ironic function within the texts, as well as towards the actual scenes the texts depict.

Texts that have a primarily aesthetic function are: "a Spanish motif of a lady with a fan, wearing black lace” (Francisco Goya, Queen Marie-Louise, 1814); “... the marble legs of a nude goddess" (Théodore Géricault, Leda and the Swan, 1780); “... blue blemishes on a linen blouse under a brownish shade of a row of trees" (PierreAuguste Renoir, The Swing, 1876); “... a Hellenic motif of white horses” (Théodore Géricault, Slaves Stopping a Horse, 1817); “... a peasant girl in a carriage, wearing black in contrast to her pallid complexion, thus intensifying the contrast" (Edvard Munch, Anxiety, 1894); “... silver spring rain of Van Gogh's Bernheim” (Vincent van Gogh, Bridge in the Rain, 1887) (ibid.).

Texts containing critical descriptions are those of Byzantine frescoes: “... the allegory of a baby in nappies, exhaling its dying breath upon Byzantine frescoes, that little doll held by angels and the Madonna as a symbol of her soul, it is an apparition, nevertheless it was a moral compass and the symbol of holy love, yet, despite this holy moral compass, men have been slaughtering each other for eons..."; or a direct allusion to Piero della Francesca's masterpiece Battle between Heraclius and Chosroes (1466): “... if, for example, one could find a painter who could paint this mad Babylonian time, so he could show us that every square millimetre of our civilisation hides a multitude of decaying human skulls it, verily, would not be deemed a 'good painting' in accordance with today's tastes, but one Piero della Francesca would indeed take upon himself this very endeavour..."; or the Supper at Emmaus by Rembrandt van Rijn

24 Krležàs "synthesis" is a holistic, all-encompassing and immediate approach to "images" of reality without "the veil of learned schemes, for people are taught not to see, but to go blind." Or, as the philosopher Francis Bacon, who was very familiar to Krleža, would say, without "false idols".

25 Days Long Past includes diary entries from 1914 to 1921, and was published as a stand-alone publication in 1956 by Zora, a publishing house from Zagreb. In 1977, Days Long Past was published by Oslobođenje from Sarajevo as a companion to Diaries $(I-V)$, along with the first two volumes, Diary I and II. 
(1628/29): “... opposing one historic anecdote lies the entire European history, which is also an anecdote, a gory one, with no one talented enough to paint it..." (ibid.).

Ironic descriptions are generally used to illustrate narrative kitsch or abstract paintings: “J'arrose mon jardin' - this is how Paul Klee mocked his own work, pouring water from a tin bucket over his own watercolours each morning, wondering how his phantasms blossomed into unexpected assortments of colours and tinges..." (ibid.) (Paul Klee, Rose Garden, 1920). We find interesting, ironic turns within descriptions of monumental paintings, in such a way that their religious or political content is reconstructed and re-enacted within a new context (theme). Krleža was especially interested in Beato Angelico, and the Italian Renaissance as a whole.

When talking about Beato Angelico's “... sweet and clear, blue watercolour" ${ }^{26}$ from Days Long Past, his detailed and richly re-enacted ekphrasis can be recognized in the second version of the Annunciation, ${ }^{27}$ if we are to judge on the basis of the details and techniques mentioned. A layered description of this picture can be found in the novel At the Edge of Reason: “... the boy is lovely, translucent, a peculiar, mysterious light emanates from him, the same light that springs from beneath antiquated layers of varnish on Quattrocento temperas: before Mrs. Jadviga, there stood Gabriel in a red tunic, embroidered with gold tassels, bringing forth good tidings ..." (Krleža, 2004, 88). Here, Krleža makes a paradigmatic example of an ironic turn ${ }^{28}$ by using the prototype of a sacral theme of a great master in order to cite reality, as a contrast. Beato Angelico's painting of the Annunciation, portraying the angel Gabriel (in Krleža's text, "the literary fledgling Gabrijel," entering through that "filthy door into the literary world") bringing good tidings to Mary (in Krleža's narrative, we have the cold-hearted Jadviga, "as cold wives of famous literary magazine editors usually are, they make crêpes and open doors for literary novices to whom Gabrijel brings his first manuscripts)" (Krleža, 2004, 87). The literary associations are accompanied and unified via ideasthesia, by use of auditory stimuli, and thus: “... while the bell of annunciation echoes across valleys and over vineyards, the broken toilet cistern murmured through the porch and that fantastic event dissipated like incense" (Krleža, 2004, 88).

26 Fra Angelico, Annunciation, c. 1437, fresco in the Convent of St. Mark, Florence. Krleža uses the term "watercolour" probably thinking of the "wet" fresco technique which separates this particular work from other depictions of the Annunciation by the same artist.

27 Fra Angelico, Annunciation, c. 1425-28, tempera on wood with gold inlays, Prado, Madrid.

28 Compare Rorty (1995) and Biti (1997, 155-157) According to Rorty, the ironic language of digression is laden with re-descriptions and unexpected "new" descriptions, in the service of two assumptions: one that claims that the difference between the aesthetic and moral should be erased, and one which asserts that the differences between public and private human interventions and interpretations should be established. From the Pojmovnik suvremene književne teorije (Biti), irony is possible only in a dynamic discourse, and all of us are usually part of more than one of these discursive communities. 


\section{Conclusion}

The art of writing (Lat. ars scribendi), as used by Miroslav Krleža in the first quote of this paper, is "descriptive" as well as "dangerous" - a "descriptive skill". Writing is almost equated with the function of observing. It can be a nucleus that the author covers in layers of observation, and, quite the opposite, writing can be the peeling off of all layers in order to get to the core of authentic, observational experience. Above all, writing is obviously a process, and one that is never-ending, being both artistic and inquiring in essence. One thing is certain, if there are two paths to such inquisitive efforts, one that escapes from the world into fantasy, and one that resists fantastic depictions of the world, then Miroslav Krleža's path is focused on reality, as reality is, inspirational enough to create images of pure beauty as well as unimaginable horror. One question remains: why does Krleža resort to using real paintings and sculptures, real cities, artists, architects, museums and galleries ..., just so he can make them an integral part of his fictional texts? One of the possible answers is presented here. Reality is, as Krleža continuously highlights in his works, incorporated into life as a mark of experience, the same way man leaves traces on the living tissue of history through art. In other words, if experience is a mark left on our memory, intellect, conscience as well as aesthetic preferences, art, then, is a trace on the common, social tissue of history that resists being forgotten. On this topic, Krleža writes: “... and Michelangelo left on the walls of the Sistine nothing but a trace of humanity the same as that Cro-Magnon, that gorilla, who in the cave of Altamira, left his bloody, beastly, man-eating handprint" (Krleža, 1933, 8). The descriptions of pictures in Krleža's texts depict, invoke, associate, suggest, and question the traces and types of traces art makes throughout history; the nature of their quality and the social impact of an artist, of a human's handprint on the walls of the Sistine Chapel or Altamira - it matters not. The types of ekphrasis mentioned in this paper instantiate this principle of witnessing reality through art, while hiding in pictures the same way concepts do so. Krleža is an artist in whose opus the artisanal and creational ("Euclidian") are forever in opposition. He detects and describes these two types of creation on the pages of his most famous essay, Marginalia on the painting of Petar Dobrović (1921). Here, two entities are opposing each other - the artiste (artisan) and the artiste (intellectual). Each stands his own ground, in opposition to the other. Using the archaic expression "artiste" (artisan, hudožnik), ${ }^{29}$ Krleža describes an artist deeply immersed in the dark part of his being, the subconscious, the murky, the unknown, the diabolic, the hellish, the side of the "dark forces", the side that conceals reality from the mind ... Such an

29 Hudožnik is an archaic term for an artist, derived from the Russian word: xudóžestvo (hudožèstvo), meaning art. Krleža partly derives this description from the archaic term "hude sile" ("dark forces") as dark, heavy, malevolent and unfamiliar, and above all, impossible to explain rationally. 
artist, inscribing his soul as Faustus to Mephistopheles, in the eruptive act of creation, in the feverish intensity of life, in contact with the subconscious, leaves his artistic mark and reaches down to the very core of his being, deeper than can be achieved by intellectual activity. On the other hand, the artiste (intellectual, umnik) creates within a firm intellectual framework, depicting only that which can be "tangibly real". He does not analyse himself in a Faustian fashion for he "sees things shallowly barbaric and guilelessly deep," which, despite the imperatives of modernism, is not a false or a decadent primitivism. As in the ancient tale, he is the painter Zeuxis, who painted grapes in such a realistic manner that birds pecked at the picture. One issue remains unanswered: whether some other Parrhasius will drape these "grapes", as did the one in the myth. It seems that, in the inquisitive quest for hidden ekphrasis, two drives compete - that of Zeuxis to describe and that of Parrhasius to hide by means of description. They are artists like the Demiurge and Faustus, an intellectual (umnik) and an artisan (hudožnik). The former always describes things as they are, constructing realities on the basis of Euclidian rules, while the latter veils the old reality through a metaphysical "curtain" of the new. The former falls for the ruse yet again, as if the added "curtain" is a new, undiscovered aspect of reality. The many ekphrasis in Krleža's texts are a demiurgic replenishment of art historic reality, while hiding under the "curtain" of fiction, preventing its co-existence with the ordinary world by means of a "dark force".

\section{References}

Biti, V., Pojmovnik suvremene književne teorije, Zagreb 1997.

Flaker, A., Banket u Blitvi, Krležijana A-LJ, Vol. 1, (ed. Visković, V.), Zagreb 1993, p. 47.

Flaker, A., Na rubu pameti, Krležijana M-Ž, Vol. 2, (ed. Visković, V.), Zagreb 1999, p. 76.

Goodman, N., Languages of art: an approach to a theory of symbols, Indianapolis 1968.

Heffernan, J. A. W., Ekphrasis and Representation, New Literary History 22. 2, 1991, pp. 297-316.

Krleža, M., Antun Augustinčić, Zagreb 1968.

Krleža, M., Banket u Blitvi, I-III, Zagreb 2000.

Krleža, M., Djetinjstvo u Agramu 1902-03, Republika 12, 1952.

Krleža, M., Dnevnik I 1914-17, Sarajevo 1977a.

Krleža, M., Dnevnik II 1918-22, Sarajevo 1977b.

Krleža, M., Drame, Sarajevo, Zagreb 1977.

Krleža, M., Eseji I, Zagreb 1932. 
Krleža, M., Eseji IV, Marginalije na temu o spoznajnoteorijskoj magiji, Zagreb 1963.

Krleža, M., Eseji VI, Zagreb 1967.

Krleža, M., Gospoda Glembajevi, Zagreb 2002.

Krleža, M., Na rubu pameti, Zagreb 1960.

Krleža, M., Povratak Filipa Latinovicza, Zagreb 2002.

Lah, N., Likovne koordinate u djelu Miroslava Krleže [Visual art Coordinates in the Work of Miroslav Krleža], 2009, unpublished.

Langer, S., Filozofija u novom ključu, Beograd 1967.

Moxey, K., Semiotika i socijalna povijest umjetnosti. Umjetničko djelo kao društvena činjenica, Zagreb 2005.

Rorty, R., Kontingencija, ironija, solidarnost, Zagreb 1995.

Srhoj, V., Ivan Meštrović i politika kao prostor ahistorijskog idealizma, Ars Adriatica 4, 2014, pp. 362-384.

Wagner, P. (ed.), Icons-Text-Iconotexts: Essays on Ekphrasis and Intermediary, New York 1996.

Yacobi, T., Pictorial Models and Narrative Ekphrasis, Poetics Today 16.4, 1955, pp. 599-464. 


\section{Nataša Lah \\ Skrita ekfraza v delih Miroslava Krleže}

Ključne besede: Miroslav Krleža, leposlovni kriptogram, skrita ekfraza, fikcijska ekfrazna vsebina, ekfraza in resničnost

V celotnem opusu Miroslava Krleže lahko najdemo številne verodostojne opise, ne oziraje se na to, ali opisujejo resnične zgodovinske dogodke ali resnične umetnike in umetnine, ki so bogat vir evropske umetnostne zgodovine. S tem ko je opise s kriptografsko metodo vključil v besedilo, je Krleža na eni strani zakril svoje vire, na drugi pa jih je razkril. Potajil jih je v preplet fikcijskih besedil in jih razkril prek ključne stvaritve, kar je bilo jasno le tistim, ki so lahko povezali besedilo in umetnino. Sklop take metode smo poimenovali leposlovni kriptogrami, ki jih lahko $\mathrm{v}$ nadaljevanju razčlenimo $\mathrm{v}$ tematske podskupine prikritih umetnostnih opisov, tako da smo celoto označili za skrito ekfrazo. Izbor umetnin, ki jih Krleža opisuje v svojih delih, je obsežen in raznolik, vsako delo pa je opisano drugače. Ker pa gre za literarna besedila, so opisi pogosto uporabljeni v širokem razponu interpretativnih upodobitvenih strategij. Do določene mere so bili zgolj pogled na umetnino z namenom, da bi vizualno povezali, obudili ali postali natančen simbol nesnovnega okvira umetnikove misli oziroma celotnega družbenega konteksta. Drugikrat je umetnina polno in natančno predstavljena zaradi svojega pomena in verodostojnosti, ker ima po Krležu "etično inteligenco« in »etično zavest«. V tem prispevku so bila obravnavana samo Krleževa prozna dela, in sicer na dveh ravneh. Ogledali smo si primere, kjer je resnično umetniško delo v leposlovno besedilo vključeno z namenom, da bi podčrtalo pomen in smisel nekega dialoga, mise-en-scène ali situacije. Tega je mogoče največ najti v odrskih delih, romanih in novelah. Po drugi strani pa lahko prepoznamo popolnoma nasprotno metodo, ko umetniško delo vstopi v besedilo, kjer zaradi svoje zgodovinske vloge in nesporne veljave oziroma statusa ponovno vstopi v resničnost. Kakor je videti s stališča Krleževega življenja in dela, je umetnina postavila na preskušnjo verodostojnost umetnostne zgodovine skozi matrico sodobnosti. To povečini najdemo v Krleževih esejih, kritikah in dnevniških zapisih. 


\section{Nataša Lah \\ Hidden Ekphrasis in the Works of Miroslav Krleža}

Keywords: Miroslav Krleža, belletristic cryptogram, hidden ekphrasis, fictional content of ekphrasis, ekphrasis and reality

Throughout the entire literary oeuvre of Miroslav Krleža we are faced with a great number of credible descriptions, describing real historic events, or real artists and artworks belonging to the rich resources of European art history. By applying a cryptographic method of incorporating descriptions into his texts, Krleža on the one hand hid his sources, while on the other also revealed them. He hid them in the tissue of fictional texts, and unmasked them using a key work only those familiar with the source could identify. We term this method the use of "belletristic cryptograms", and can further categorise it into thematic subgroups of concealed artwork descriptions, naming this whole method the use of hidden ekphrasis. The choice of artworks Krleža describes in his work is comprehensive, diverse and each described differently. Since we are dealing with literary texts, descriptions are often used in the function of a wide array of interpretative strategies of depiction; in some aspects, they are used as a mere glimpse into a piece of art with the goal of visually associating, evoking or minutely symbolizing the incorporeal frame of an artist's mind or of the wider social context. In other aspects, the artworks are richly and meticulously presented with regard to their importance and credibility as they, according to Krleža, possess an "ethical intelligence" and "ethical conscience". Only Krleža's prose is researched here, and this is done on two levels. We take a look at examples where real art is incorporated into fictional texts in order to determine the significance and meaning of a certain dialogue, mise-en-scène or situation. This is most commonly found in the author's plays, novels and novellas. On the other hand, we can trace a completely opposite method by which artworks enter these texts, where, due to their historic determination and already established worth/ status, they thus re-enter reality, as seen from the perspective of Krleža's life and work, so as to yet again test art history's credibility through the matrix of contemporaneity. This approach is most often found in Krleža's essays, critiques and diary entries. 